\title{
KIRSAL ALANDAKİ ENGELLÍLERIN SORUNLARI VE ETKİLEŞİM FARKLILIKLARI
}

\section{Serdar Nerse*}

$\ddot{O} \mathbf{z}$

Engellilik kavramsal açıdan sosyal bilim ve diğer bilim alanlarında çokça çalışılan bir konu olsa da "kırsal alandaki engelliler"in sorunları yeterince çalışılmamıștır. Dolayısıyla kırsal alanda engellilerin durumunu ortaya çıkaracak çalışmalara ihtiyaç bulunmaktadır. Bu araştırmanın amacı sosyoloji alanyazınında tartışılmayan kırsaldaki engellilerin sorun ve durumlarını farklı bileşenlerle tartışmaktır. Araştırma Türkiye'nin sosyoekonomik bakımdan en dezavantajlı illerinden Mardin, Batman ve Şınak'ın köylerinde yürütülmüştür. Mardin, Batman, Şırnak illeri ile bu illere bağlı köylerde yaşayan iki engelli grubuyla çalışılmıştır. Araştırma kırsal alanda ikamet eden, hastane veya rehabilitasyon merkezlerinde yatılı kalmayan iki farklı grupla yapılmıştır. Araş̧ırmada nicel araştırma yöntemi kullanılmış olup, iki gruba ayrılan toplam 192 kişiye anket uygulanmıştır. Katılımcılar amaçsal ve küme örneklemeyle belirlenmiştir. Kırsal alandaki engellilerin i) eğitim, ii) istihdam, iii) evlilik durumlarl, iv) duygusal problem, v) sosyal düzenlemeler ve aile algisı ile vi) toplumsal aktivitelere kattlim durumlarına ilişkin sorular sorulmuştur. Bu değişkenler bağlamında katılımcıların engellilik durumları ve toplumsal yaşama katılımları arasındaki ilişkiye bakılmıştır. Araştırma neticesinde kırsal alanda yaşayan engellilerin sosyal durumları, ekonomileri ve diğer ilişkilerinde olumsuzluklar olduğu tespit edilmiştir.

Anahtar Kelimeler: Engelli Problemleri, Eşitsizlik, Dezavantajlı Gruplar, Kır Sosyolojisi, Kirsal Alandaki Engelliler.

\section{PROBLEMS AND INTERACTION DIFFERENCES OF DISABLED PEOPLE IN RURAL AREA}

\begin{abstract}
Disability is a subject that has been studied a lot conceptually. However, studies on the problems of "disabled people in rural areas" are few. Therefore, such studies are needed. The aim of this study is to discuss the problems of disabled people in rural areas, which are not discussed in the sociology literature, with different components. The research was conducted with two disabled groups who live in socioeconomically disadvantaged villages of Mardin, Batman and Şırnak, and who do not stay in hospitals or rehabilitation centers. Quantitative research method was used in the research. A

Article Types / Makale Türü: Research Article / Araştırma Makalesi

Received / Makale Geliş Tarihi: 03/06/2020, Accepted / Kabul Tarihi: 26/08/2020

DOI: https://doi.org/10.26791/sarkiat.747340

* Batman Üniversitesi, Fen-Edebiyat Fakültesi, Sosyoloji Bölümü, serdarnerse@ yahoo.com

ORCID ID: https://orcid.org/0000-0002-2048-9478
\end{abstract}


questionnaire was applied to a total of 192 people divided into two groups. Participants were determined by purposeful and cluster sampling. Disabled people in rural areas were tested for i) education, ii) employment, iii) marital status, iv) emotional problems, v) social arrangements and family perception, and vi) participation in social activities. In the context of these variables, the relationship between the disability of the participants and their participation in social life was examined.

Keywords: Disability Problems, Inequality, Disadvantaged Groups, Rural Sociology, Disabled People in Rural Areas.

\section{GİRIŞ: ENGELLILIKK ÇALIŞMALARI, TANIMLAR VE FARKLILIKLAR}

Engellilik sorunu sağlık bilimleri başta olmak üzere mimarlık, hukuk, siyaset bilimi, sosyal politika, psikoloji gibi diğer alanlarda çalışılmıştır. Sosyolojide de toplumsal sorunların kökeni, diğer faktörlerle ilişkisi ve çözümlerine ilişkin özellikle çağdaş dönem düşünürleriyle tartışma alanı bulmuştur. Toplumsal yaşamın her aşamasında farklı engellerle karşılaşan bu bireylere yönelik çalışmalar farklı disiplin ve alanlarda yürütülse de engelliliğin durumu, yeri, yaklaşım biçimleri, çalışmaların türü ve sıklığ1 birbirinden farklılaşabilmektedir. İnsan ırkıla aynı tarihe sahip olmasına rağmen, engellilik uzun dönemlerce tanımlanmamış, engellilerin deneyimleri ve engellilik sorunlarının tasfiyesi genel akademik çevrede uzunca bir süre dikkate alınmamıştır (Oliver, 1990, 23). Engelliliğe ilişkin çalışma ve yaşam alanlarına yönelik hareketlenmeler, özellikle İkinci Dünya Savaşı'ndan sonra sosyal reçeteler, sosyal düzenleme ve toparlanmalar olarak sunulmuştur (Yakkaldevi, 2014, 1). 1960'lı yılların sonlar1, 1970'lerin başından itibaren de sosyal özgürlüklerin gelişimi halini almıştır. Özgürlük seçimi, genel eğitim ve engellilere ayrılan eğitim ile eğitim alanı çevresinde yeni tartışmaları ortaya çıkarmıştır. Okula giden engellilerin sayısının artması ve engelli kişiler arasında yetenekli yönetimin verdiği konsolide itici güç ile hız kazanmıştır (Scotch, 1989). Engelliliğin tanımlanması ve engelli bireylere ilişkin araştırma ile sorunlarına çözüm üretme son yüzyılın özelikle ikinci yarısından itibaren farklı disiplinlerde yürütülen çalışmalara konu olmuştur. Ancak, engelliliğin halen çözüm üretilemeyen ya da çözümsüz bırakılan pek çok yönü de bulunmaktadır. Bunun için engellilerin yaşam şartlarının iyileştirilmesi konusunda farklı disiplinlerden çalışmalara ihtiyaç devam etmektedir.

Dünyada olduğu gibi Türkiye'de de kentsel ve kırsal alanda engelli bireyler yaşam şartları ve standardı olarak, politik alandaki hakları nedeniyle istismara uğramaktadır. Yeterli sayıda ve nitelikli işlerde istihdam edilmemekte, toplumun bakışı nedeniyle sosyalleşme sorunları yaşamakta, eğlence ve spor hayatına katılımları sınırlanmakta veya dışlanmaktadırlar. Benzer olumsuz durumlarla karşı karşıya kalan engelliler uzunca bir dönem sorunlarıyla yalnız mücadele etmek zorunda kalmışlardır. Toplumsal alandaki engelli vatandaşlar ile engelli olmayanlar arasında belirgin farklılaşmalar devam ederken, engelliler kentte veya kırda farklı şekillerde ötekileştirilmektedir. Her ne kadar "fiziksel, zihinsel, düşünsel ya da algısal bozukluk" (Resmi Gazete, 14 Temmuz 2009, 15137) şeklinde sinırlandırılsa da engellilik aynı zamanda toplumsal ilişki, oluşum ve süreçlerden de engellenmeyi içermektedir. Schneider ve Conrad (1983)'ın epilepsi hastalarıyla, O'brein (1983)'ın hemodiyalize bağl1 olanlarla görüşerek fiziksel biçimiyle tanımladığ 1 engelliliği, Corbin ve Strauss (1985) ise bir iş gerekirliliği ve sosyal sürecin diğer bireylerle karşılaştırılabilirliği üzerinden farklı bir şekilde anlamlandırmıştır. Farklı tanımlamalar, genel itibariyle ister fiziksel, ister zihinsel, ister düşünsel ya da algısal nedenlerle engeli olan bireylerin 
ötekileştirilmesine, diğer bireyler tarafından toplumsal alanda farklı süreçlerde engellenmesine ya da damgalanmalarına neden olmaktadır. Gerek kentte gerekse kırda ötekiyle karşılaşıldığında tedirginlik ortaya çıkmakta, çoğunlukla birbirine benzeyenlerin aynı yer veya mekanlarda yaşamak istemeleri diğerine karşı dışlayıcı pratikleri (Doğanay \& Henden, 2016) ortaya çıkarmaktadır. Engellilik uluslararası sınıflandırmaya göre, kısaca sağlıklı organın bozulmasından kaynaklı, insan sağlığının fiziksel yönleriyle bozulması nedeniyle kapasite kaybı (WHO, 29 Şubat 2020) olarak tanımlansa da sosyal, ekonomik ve kültürel ölçütler başta olmak üzere toplumsal alanda bir değer ölçüsü (Hosain vd., 2002, 297) olarak eksiklik de engellilik olarak tanım bulmuştur. Dolayısıyla engellilik durumu, yalnızca yetilerin kaybolması veya yitimi olarak tanımlanamaz. Engellilik durumu aynı zamanda, gündelik hayatta mekanda ve mekan içerisinde meydana gelen dişlanma, izolasyon, uzaklaştırılma ve damgalanma gibi sosyal etkileşimlerle de ortaya çıkabilmektedir. Engellilik fiziksel sağlığın yanı sıra, yukarda da değindiğimiz gibi farklı şekillerdeki engellemelere maruz kalan insanların aile, arkadaş ve komşularıyla sosyal ilişkilerini, yaşamını, psikolojik durumlarını ve bağımsızlık seviyelerini de etkiler (Barbotte vd., 2001). Bireysel bir sorun olarak görülse de toplumsal alandaki kurumsal erişim problemleri engelliliği daha açık bir şekilde belirginleştirmektedir. Engellilik, aynı zamanda toplum üzerinde önemli ve yaygın sonuçları olan (Kurawa, 2010), sosyal düzenleri önemli ölçüde etkileyen bir olgudur (Barnartt, 2011). Söz konusu yaklaşım biçimleri çoğunlukla engellilere yönelik negatif bir ilişkiyle gerçekleşirken, toplum yönünde de etkileşim ve bütünleştirme eksikliğini ortaya çıkarmaktadır. Bu nedenle, toplumsal alanda her bireyin karşılaştığ1 olağan ve temel sorunlar haricinde engelli bireylerin ayrıca uğraşmak zorunda kaldığ 1 sorunlarıyla hayat karmaşık bir hal almaktadır.

Sorunların karmaşıklaştığ1 ve ayrımlaştı̆g temel alanlar olarak kentte ve kırda engelli bireylerin kamusal alana erişimleri, muhtaçlık durumları, beklenen rol ve tutumları inceleme konusu olmuştur. Kursal toplumsal alandaki ilişki ve oluşumlar henüz daha yakınken, kişisel özellikleri nedeniyle engelliler kırsalda dahi genel toplumsal algı ve çevresel engellemeler karşılaşabilmektedir (Thompson vd., 2011). Dolayısıyla kentsel alanda; eğitim, ulaşım, iletişim, politik katılım ve daha bir çok konuda düzenlemeler yeterli duruma henüz getirilmemiş olsa bile onarılırken, kırsal alanda ise bu çabaların yetersiz olduğu görülebilmektedir. Türkiye kırsallığında engelliliğin görünümüne ilişkin yeterli düzeyde araştırmanın bulunmadığı kırsal alanlarda benzer çabayla koşulların daha yeterli duruma getirilebilmesi kapsamlı çalışmalara bağlıdır. Merkezden uzak yerlerde bu kesimin durumu çok görünür değildir. Dolayısıyla engelliliğin kırsaldaki görünümünün farklı çalışmalarla desteklenmesi ihtiyacı ortadadır. Engellilik olgusu kırsal ve kentsel alanda yapılan çalışmaların çeşitlendirilmesiyle tıbbi ve psikolojik modellemelerin tahakkümünden kurtarılarak, aynı zamanda engellilerin sosyal ve diğer yönleriyle haklarının desteklenip geliştirilmesine imkan oluşturulacaktır. Toplumsal bir olgu olarak engelliliğin modellenmesi ve sosyal alandaki teorik perspektifle tartışılmasından ziyade, kırsal alanda sunulan hizmetler kırsal toplumsal alandaki engellilerin verileriyle değerlendirilecektir.

Karmaşıklaşan kentsel alanda engelliliğin görünür kılınmasına yönelik çabalar doğrudan engelli bireyler ile belli bir destek buldukları diğer grup ya da kuruluşlarca devam ettirilmektedir. Bir yönüyle hor görme, dışlama, ayıplama mekanizmasının etkin bir şekilde çalıştığı kır hayatı da hem engellilerin özgürlüklerini sınırlayabilmekte hem de onlara daha güvenli ve korunaklı bir yaşam alanı sunabilmektedir. Dolayısıyla kır kent arasındaki çelişkiler günden güne artarken, kentte ve kırda engelliliğin görünümüne yönelik farklılaşmalarda da artmaktadır. 


\section{Araştırmanın Amacı ve Metodolojisi}

Toplumsal alandaki sorunlar, sorunların ortaya çıkış sebebi ve yarattığ 1 etkiler farklı bilimsel perspektiflerle tartışılan meselelerdir. Sorunlara ilişkin tartışmalar, çoğunlukla uygun bilimsel ve metodolojik bir yaklaşımla incelenmek istenmektedir. Araştırmanın niçin yapıldığı ve kaç kişiyle hangi teknikle yapılması gerektiği, analiz biçimleri yöntemsel farklılaşmaları ortaya çıkarmıştır. Aynı şekilde, yöntem ve tekniğin yanı sıra, çalışmaya dahil edilecek katılımcılar da uygun araştırma birim veya nesnelerinden seçilmelidir. Çalışma amacına uygun ve araştırılacak olgu ile bileşenler arasındaki uyum çalışmanın yapılabilirliğini, amaca uygun verilerin elde edilmesini sağlamaktadır. Toplumsal yaşamın farklı yönlerinde, anlarında, hız ve miktarındaki değişimler sorunların tespitinde farklılaşmalara neden olduğundan, belirli bir yöntem ve tekniği gerektirse de özgün düşünme biçimi, çözüm ve analizle de mümkün olabilmektedir (Denzin \& Lincoln, 2005). Dolayısıyla, kırsal alanda yaşayan engellilerin karşılaştığ1 sorunlara benzer biçimde, sorunların yoğun olduğu bir alanda derinlikli bir analize ihtiyaç vardır.

Toplumsal sorun ile sorunlara uygun çözüm önerileri, konuya ve konunun ele alınma biçimine göre farklılaşabilmektedir. Toplumlar için temel akım noktası ve takip hedefi durumundaki gelişmiş ülkelerdeki sağlık ve diğer toplumsal koşullardaki iyileşmeler neticesinde; farklılaşmış ayrıcalıklı grupların yanı sıra henüz toplumsal alanda bir ayrıcalık edinmemiş marjinal grupların dahi yaşamında iyileşmeler meydana gelmektedir. $\mathrm{Bu}$ yerlerde engellilerin de durumları incelendiğinde yaşam kalitelerinde iyileşmeler fark edilebilmektedir. Türkiye'de de engelli sorun ve yaşamsal etkileşimleri eskisi gibi değildir. Engellilerin toplumsal yaşamını anlamaya, koşullarını iyileştirmeye yönelik çabalar kısa bir dönem önce başlamıştır. Türkiye'de engelliliğin durumunu anlamaya yönelik çaba ve çalışmaların önemli bir bölümü kurumsal hizmetler şeklindedir. Bilimsel çabaların yanı sıra, duyarsızlık, engellilere yönelik zulmün engellenmesi ile acımayla ilişkili yardımlar iyi niyetli çabalar olarak yürütülmektedir. Kırsallıkta gelişmişlik ve gelişmemişlik durumu çoğunlukla kurumsal çabalara bağlı kılındığından, sosyal ayrımlar, farklılaşma durumları incelikli bir şekilde bilinememktedir. Kırsallığın dezavantajlı görünümleri bu açıdan, araştırmada merak unsurudur. "Kırsal engelliliğin sosyal ayrımının yaygınlı̆̆g”" (Brown, 1988) gerçeğinden hareketle, Türkiye'de kırsal engellilerin istismarlarının önüne geçilmesi, eğitilmeleri, istihdam edilmeleri ve yerinde rehabilite edilmelerine ilişkin temel değişkenlerin araştırılabileceği dezavantajlı bir kesim aynı şekilde dezavantajı ıir bölgede inceleme konusu edilmiştir. Mekansal bağlamda kırsal alanda bulunma ile engellilerin etkileşim ve sorunlarının incelenmesi amaçlanmaktadır. Çalışmada, Kırsal alandaki engellilerin i) eğitim, ii) istihdam, iii) evlilik durumlarl, iv) duygusal problem, v) sosyal düzenlemeler ve aile algısı ile vi) toplumsal aktivitelere katılım durumlarına ilişkin değişkenlerdeki farklılaşmaların nicel yöntemle incelenmesi amaçlanmıştır. Genel olarak engellilikle ilişkili çalışmalar olmasına rağmen, söz konusu çalışmalar çoğunlukla engelliliğin ne olduğu, fiziksel engellilik ve engellilerin sağlik durumuyla ilgilidir. Bu araştırmada kişisel özellikler temelinde kısmi sosyo-politik bağlamlar ve kurumsal çabaların kırsal alandaki engellilerin etkileşim ve sorunlarına etkilerinin de incelenmesi çalışmaya önem katmıştır. Kırsal engelliliğin dezavantajlı bir bölgeyle sınırlandırılarak araştırma sonuçlarıyla değerlendirilmesi diğer bir odak noktasını oluşturmaktadır.

Çalışma, derinlikli bir şekilde ayrımları görebilmek için kırsal alan ve diğer toplumsal gelişmelerle birlikte sosyoekonomik açıdan gelişmemiş bir bölgeyi ifade etmesi açısından Batman, Mardin ve Şırnak köyleriyle sınırlandırılmıştır. Dezavantajlı bir 
bölgede en dezavantajlı grup şeklinde amaçsal örneklemeyle bir alt aşamaya geçilmiştir. Üst aşamada belirlenen araştırma evreni sonrasında çalışma grubu fiziksel, ruhsal, düşünsel, zihinsel, duyusal ve algısal engellilik durumları dikkate alınarak iki gruba ayrılmıştır. Araştırma kapsamında kümeleştirilen gruplar; i) sadece belirli zaman dilimlerinde rehabilitasyon merkezlerine gelen ruhsal, düşünsel, zihinsel ve algisal bozukluğu olanlar ile ii) çoğunlukla köylerinde ikamet eden bedensel ya da diğer fiziksel engelliler şeklinde ayrımlanmıştır. İki gruba ayrılan bireylerin durumları yakın bir eşitlik ve genel bir dağılım dikkate alınarak incelenmiştir. Araştırmanın sınırları dolayısıyla, kentte ikamet edenler ve kentteki hastane ile yatılı rehabilitasyon merkezlerinde sürekli olarak kalan engelliler araştırmaya dahil edilmemiştir. Kırsal alanda yaşayan engellilerin durumu araştırılmak istendiğinden, araştırma birimine dahil edilen bireylerin (günün belirli saatlerinde eğitime gelenler dahil) tamamı köylerden ve beş yaş ile üstü olacak şekilde seçilmiştir. Ancak araştırma kapsamında görüşülen bireylerin kentte bulunan imkanlardan tamamen yoksun olması gerektiği anlamina gelmemektedir. Ancak, sürekli olarak şehir merkezlerinde ikamet eden, hastane ve merkezlerde kalanlar araştırmaya dahil edilmemiştir. Çalışmanın araştırma popülasyonu köylerin olağan sakinleri durumunda olan engelli bireyler olsa da cevap veremeyecek durumda olanların bilgileri bakıcılarından elde edilmiştir.

Araştırmanın ilk aşamasında standart bir biçimde düşük puanlı (yıkanma ve giyinme dahil günlük etkinlikleri yerine getirememe veya kısitlılık) ve yüksek puanlı (kısıtlılık olmaksızın tüm etkinliklerini yerine getirme) engelli bireyler ayrımlanmıştır. Engelli bireylerin günlük aktivite, genel sağlık ve duygu durumları SF-36 (Orthotoolkit, 30 Ekim 2019)'daki 10 soruyla belirlenmiştir. İkinci aşamada birinci gruptan 102 ve ikinci gruptan 90 kişi olmak üzere toplam 192 engelliye, yukarıdaki değişkenler çerçevesinde oluşturulan eşit dağılımlı, ortak sorulardan oluşan ve ağırlıklı olarak toplumsallaşma durumlarını tespit etmeye yönelik bir anket formu uygulanmıştır. Anket soruları; yine eğitim, istihdam, evlilik durumları, duygusal problem, sosyal düzenlemeler ve aile algısı ile toplumsal aktivitelere katılım durumları gibi değişkenler ekseninde oluşturulmuştur. Bireylerin engellilik durumlarıyla yaşamlarının ne kadar etkilendiğine dair bilgiler, her bir engelli veya bakıcısından kapalı uçlu sorularla elde edilerek, araştırma verilerinin elde edilme süreci bu haliyle temelde iki aşamada sonuçlandırılmıştır. Öncelikle, "normal olarak kabul edilen aralığın dışında olmak ve bu aralığın dişında faaliyet gerçekleştirmek" (WHO, 29 Şubat 2020) şeklindeki sınıflandırma ve uluslararası ölçeğe alınmıştır. Ancak, engellilik tek bir ölçekle sınırlandırılamayacağından ikinci aşamada engelli sorun ve etkileşimlerinden oluşan tam yapılandırılmış bir soru formula veriler toplanmıştır. Toplanan veriler bağımsız değerlendirmelerle yorumlanmıştır. Bu nedenle, 2019 yılı Ağustos ayında başlatılan araştırmada yeterli ve nitelikli veriler elde edilmek istendiğinden, çalışmanın saha uygulaması 3 ay sürmüştür. Nihayetinde, tablolaştırılmış veriler birebir rakamsal very sunumundan ziyade, zengin literatürle derinlikli bir şekilde yorumlanmıştır.

Kırsal alandaki engellilerden elde edilen verilerle gerçekte durumlarının ne olduğu ve nasıl toplumsallaştıklarını doğru bir şekilde yansıtmak için veriler kapsamlı bir şekilde değerlendirilmiştir. Dolayısıyla engelli bireylerin yaşadığı yerlerde modern olanaklara sahip çekirdek aile özellikleri görülse de sosyo-demografik yönleriyle benzer ve güçlü geniş aile bağları halen etkisini sürdürmektedir. Engellilik gibi hassas bir konuda nitelikli verilerin toplanması, araştırmacının zaman ve kültürel duyarlılığı ile katılımcıların güvenini gerektirdiğinden kırsallığın yaygın durağan ve homojen durumu dikkate alınmıştır. 


\section{2. Çalışma Bulgularının Değerlendirilmesi}

Uygulama sürecinin iki aşamalı soru ve elde edilen verileri dikkate alınarak analizler yapılmıştır. Engelliliğin toplumsal yaşama etkisiyle ilgili elde edilen veriler yeniden gruplandırılmıştır. Nicel araştırmanın doğası gereği tüm sorular katılımcıların tamamına sorulmak istense de değişken türlerine göre bazı sorular birkaç katılımcıya sorulmamıştır. Araştırma yapılan köylerde 40 ile 45 sene aralığında bir zaman dilimi öncesinde ilkokul bulunmadığından, birkaç pilot uygulama sonrasında 45 yaşını geçmiş bazı engelli bireylere okullaşmayla ilgili soru sorulmadı. Düzenli, düzensiz, maaşlı veya kısmi ücretli bir işte çalışan 15 yaş ve üstü tüm bireylere işsizliğin toplumsal yaşamlarına etkileri ile engellilik durumlarının işle ilişkileri soruldu. Benzer şekilde evlilikle ilişkili soru 18 yaş ve üstü bireylere, aile algısına yönelik sorular da örneklem grubundan hemen her bireye sorulmuştur. Araştırmalar boyunca elde edilen deneyim ve katkılara göre hareket edildiğinden kişisel ve durum soruları öncelikledirilmişstir. Dolayısıyla, analizler de öncelikle kişisel durumlarla ilişkili olmuştur.

Çalışmada katılımcıların cinsiyet rolü, yaş ve eğitim durumları ve çalışma hayatına ilişsin verilerle farklılaşmalar olup olmadığı ve olumsuzluklara yol açıp açmadıkları merak edilmiştir. Cinsiyet ve engellilik arasındaki ilişki neticesinde; engellilik, meslek ve diğer toplumsal alan, iş ile yönelimlerin de üst üste binmeye başladığ 1 görülür (Vernon \& Swain, 2002). Türkiye'deki çalışmaların önemli bir bölümü engellileri tartışırken onları cinsiyetsiz bir şekilde ele almaktadır. Cinsiyetçi bir yaklaşımla engellilik sorununa yaklaşan çalışmalar (Abu \& Habib, 1997), çoğunlukla cinsiyete göre davranış tarzının değişimiyle ilgilidir. Yaş, meslek, eğitim düzeyi ve sosyal statü de toplumsal yaşamda görünen konumlanmalara yol açsa da çoğunlukla cinsiyetsiz yaklaşımlar, az bir kısmı da işveren genç, erkek cinsiyet ve konumlanmasıyla ilgilidir. Eşitsizliğin düzenlenişi öncelikle cinsiyetsiz engellilikle şeklindedir. Sonrasında ise, aile ile toplumsal hayatın diğer aşamalarında önemli sorunlara yol açabilen işsiz, statüsüz, eğitimsiz engelliliğin önü açılmakta ve çoğunlukla eşsiz bir şekilde normalleştirilmektedir. Bu durumda engelin şiddeti normalden daha fazla arttırmasıyla (Duman \& Doğanay, 2017), engellilerin eğitim, ekonomi ve siyaset gibi diğer toplumsal alanlardan da dışlanmalarına neden olmaktadır.

Tablo 1: Cinsiyet ve yaş durumu

\begin{tabular}{|c|c|c|c|c|c|c|}
\hline \multirow[b]{3}{*}{ Yaş } & \multicolumn{4}{|c|}{ Cinsiyet } & \multirow{2}{*}{\multicolumn{2}{|c|}{ Toplam }} \\
\hline & \multicolumn{2}{|c|}{ Kadın } & \multicolumn{2}{|c|}{ Erkek } & & \\
\hline & $f$ & $\%$ & $f$ & $\%$ & $f$ & $\%$ \\
\hline $5-14$ & 20 & 10,4 & 26 & 13,5 & 46 & 23,9 \\
\hline $15-18$ & 12 & 6,2 & 18 & 9,4 & 30 & 15,6 \\
\hline $19-34$ & 24 & 12,5 & 32 & 16,7 & 56 & 29,2 \\
\hline $35-44$ & 13 & 6,8 & 11 & 5,7 & 24 & 12,5 \\
\hline $45-54$ & 9 & 4,7 & 17 & 8,9 & 26 & 13,6 \\
\hline 55 ve üstü & 6 & 3,1 & 4 & 2 & 10 & 5,1 \\
\hline Toplam & 84 & 43,75 & 108 & 56.25 & 192 & 100 \\
\hline
\end{tabular}

Çalışma verilerine göre, kırsal alanda yaşayan engellilerin büyük bölümü 35 yaş altında, özellikle yaş döneminin ilk aşamalarında ve gençlikte yoğunlaşmıştır. Engellilerin hayatını önemli ölçüde etkileyen sorunların artmasının önüne geçebilmek için engellilikle ilgili çalışmalara ağırlık verilmesi, toplumsal kamusal alandaki düzenlemelerin hızlı bir şekilde gerçekleştirilmesi gerektiği gerçeği ortaya çıkmaktadır. Yaş bakımından önemli bir durum engelli kadınların çocuklarına bakamamasıdır. Aynı 
şekilde, kadın ve erkek engelli bireylerde yaşla birlikte işsizlik sorunu ve çalışamama sorunları ortaya çıkmaya başlamaktadır. Kadınlar, kırsal bölgelerde zaten sosyal dışlanma ve ayrımcılığa maruz kalırken, engellilik durumuyla birlikte evlenme, çocuk sahibi olma ve çocuk bakımı (Karataş \& Çifci, 2010, 147) gibi durumlarda önemli dezavantajlarla karşılaşmaktadırlar.

Tablo 2: Engel grubuna göre eğitime katılım durumu.

\begin{tabular}{|c|c|c|c|c|c|c|c|c|c|c|c|c|c|c|}
\hline \multirow[b]{3}{*}{ Yaş } & \multicolumn{6}{|c|}{ Birinci Grup } & \multicolumn{6}{|c|}{ İkinci Grup } & & \\
\hline & \multicolumn{2}{|c|}{$\begin{array}{l}\text { Okul } \\
\text { bitti }\end{array}$} & \multicolumn{2}{|c|}{$\begin{array}{l}\text { Devam } \\
\text { ediyor }\end{array}$} & \multicolumn{2}{|c|}{$\begin{array}{c}\text { Gitmedi/ } \\
\text { Bıraktı }\end{array}$} & \multicolumn{2}{|c|}{$\begin{array}{l}\text { Okul } \\
\text { bitti }\end{array}$} & \multicolumn{2}{|c|}{$\begin{array}{l}\text { Devam } \\
\text { ediyor }\end{array}$} & \multicolumn{2}{|c|}{$\begin{array}{c}\text { Gitmedi/ } \\
\text { Bıraktı }\end{array}$} & \multicolumn{2}{|c|}{ Toplam } \\
\hline & $f$ & $\%$ & $f$ & $\%$ & $f$ & $\%$ & $f$ & $\%$ & $f$ & $\%$ & $f$ & $\%$ & $f$ & $\%$ \\
\hline $5-14$ & - & - & 12 & 6,25 & 4 & 1,74 & - & - & 19 & 9,9 & 11 & 5,7 & 46 & 23,85 \\
\hline $15-18$ & 1 & 0,4 & 8 & 4,16 & 7 & 3,04 & - & - & 10 & 5,2 & 4 & 2,0 & 30 & 15,44 \\
\hline $19-34$ & 12 & 6,25 & 2 & 1,00 & 12 & 5,52 & 11 & 5,7 & 14 & 7,3 & 5 & 2,5 & 56 & 29,00 \\
\hline $35-44$ & 10 & 5,20 & - & - & - & - & 9 & 4,7 & 2 & 1 & 3 & 1,5 & 24 & 12,40 \\
\hline Toplam & 23 & 11,95 & 22 & 11,35 & 23 & 10,3 & 20 & 10,4 & 45 & 23,43 & 23 & 12,0 & 156 & 80,65 \\
\hline
\end{tabular}

Türkiye'de engellilere yönelik eğitimsel yaklaşımlar çoğunlukla özel eğitim çerçevesi içinde ele alınmaktadır. Özel eğitim ülkenin her tarafında yalnızca kentsel merkezlerde verilmektedir. Kırsal alandan gelen ve eğitime katılanların nüfus yoğunluğu çoğunlukla dikkate alınmamaktadır. Çalışmada, katılımcıların eğitime katılım durumları engellilik durumlarına göre belirlenmiştir. Haftanın belirli gün ve zaman dilimlerinde rehabilitasyon merkezlerine gelen ruhsal, düşünsel, zihinsel ve algısal bozukluğu olanlar birinci gruba ve çoğunlukla köylerinde ikamet eden bedensel ya da fiziksel engelliler de ikinci gruba dahil edildiğinden bu iki grup üzerinden eğitim durumlarına bakılmıştır. Her iki gruptaki engelliler farklı düzey ve yerlerde eğitime alınmaktadır. İkinci gruptaki engellilerin önemli bir bölümü normal eğitime katılsa da yeterli düzeyde değildir. Katılımcıların önemli bir bölümü yukarıda da belirtildiği gibi 35 yaşın altındadır. Eğitim açısından kırsal alanların okullaşması ise geriye dönük 45-50 sene içerisinde yoğun bir şekilde gerçekleşmiştir. 45 yaşın altındaki nüfusun büyük bölümünün ikamet ettiği yerlerde okullar bulunmaktadır. Dolayısıyla, çalışmaya katılanların büyük bölümü eğitimle ilgili soruya cevap vermişlerdir. Her iki gruptan 45 yaş altındaki engellilerin önemli bir bölümünün eğitime devam ettiği görülmektedir. Özel eğitimin erken yaşta verilmesi ve ikinci gruptaki engellilerin de çoğunlukla normal eğitime katılabilmeleri dikkate alındığında erken dönemlerde eğitimde yoğunluk yaşandığı düşünülebilir. Ancak eğitimin bir ayağının da kentsel alanda gerçekleştiği unutulmamalıdır. Köylere yakın özel okulların bulunmaması ve yakın yerlerdeki özel okullarda da uygun araç ve ekipmanların yetersizliği engellilerin okullaşmasını etkileyen temel konulardandır (Mahapatra, 2016). Özel okullara kırsal alandan erişimin zor ve uygulamada kontrolün sınırlı olması, eğitimde devamlılığın da sınırlı olmasına neden olmaktadır. Türkiye'de özel eğitimin yaygınlaşmasıyla her iki grup engelliler için topluma eğitimli, donanımlı bir şekilde katılımlarının önünün açıldığı söylenebilir. Yine de engelliler için başkalarına muhtaç veya bağımlı kalma ya da bırakılma, eğitimde üst seviyelere çıamama, belli bir dönem sonra eğitim görememe, eğitim kurumlarına erişememe ve hatta bezı yerlerde temel eğitime ulaşamama (Orhan ve Genç, 2015, 121) sorunları halen devam etmektedir. Engellilik halini ortadan kaldırmak ya da etkilerini azaltmak, her türlü yetenek ve donanımlarını sağlamak (Milli Eğitim Bakanlığı, 2020) amacıyla engel durumları azaltılmaya çalışılsa da kapasite yetersizliği, ücret talepleri ve eğitimlerin yalnızca engelli bireylerle sınırlı tutulması, engelli yaşam eğitimlerinin toplumsal alanda yaygınlaştırılmamış olması farklı şekillerde dezavantajları ortaya 
çıkarmaktadır. Eğitime katılım durumu, süresi ve yeri nitelikli eğitim almayı etkilediği gibi iş ve çalışma hayatı ile sürecini de etkilemektedir. Benlik saygısını genişletmek için eğitimde eşit erişim imkanlarıyla birlikte, açık okul sisteminin alternatif olarak daha da geliştirilmesi gerekmektedir.

Tablo 3: Engel grubuna göre katılımcıların çalışma durumları.

\begin{tabular}{|c|c|c|c|c|c|c|c|c|c|c|}
\hline \multirow[b]{3}{*}{ Yaş } & \multicolumn{4}{|c|}{ Birinci Grup } & \multicolumn{4}{|c|}{ İkinci Grup } & \multirow{2}{*}{\multicolumn{2}{|c|}{ Toplam }} \\
\hline & \multicolumn{2}{|c|}{ Çalışıyor } & \multicolumn{2}{|c|}{ Çalışmıyor } & \multicolumn{2}{|c|}{ Çalışıyor } & \multicolumn{2}{|c|}{ Çalışmıyor } & & \\
\hline & $f$ & $\%$ & $f$ & $\%$ & $f$ & $\%$ & $f$ & $\%$ & $f$ & $\%$ \\
\hline $15-18$ & - & - & 19 & 13,0 & 2 & 1,37 & 9 & 6,1 & 30 & 15,6 \\
\hline $19-34$ & 2 & 1,37 & 25 & 17,1 & 2 & 1,37 & 27 & 18,5 & 56 & 29,2 \\
\hline $35-44$ & 3 & 2,05 & 12 & 8,2 & 5 & 3,42 & 4 & 2,7 & 24 & 12,5 \\
\hline $45-54$ & - & - & 7 & 4,8 & 2 & 1,37 & 17 & 11,7 & 26 & 13,6 \\
\hline 55 ve üstü & - & - & 4 & 2,7 & - & - & 6 & 4,1 & 10 & 5,1 \\
\hline Toplam & 5 & 3,42 & 67 & 45,9 & 11 & 7,53 & 63 & 43,15 & 192 & $\% 100$ \\
\hline
\end{tabular}

Çalışma hayatına katılımda engellilerin sosyal ve ekonomik sorunlar yaşadıkları ve engelli olmayan bireylerle karşılaştırıldıklarında yüksek işsizlik oranlarına sahip oldukları bilinen bir gerçektir. Dünya Çalışma Örgütü (ILO, 23 Ocak 2020) verilerine göre dünya nüfusunun \%15'inden (yaklaş1k 1 milyar nüfus) fazlasını oluşturan engellilerin \%80'i çalışma çağında olmasına rağmen, çalışmadan uzak veya kendi yetenekleriyle ilişkili işlerden uzak kalmaya maruz bırakılmaktadırlar.

Araştırmada 15 yaş ve üstü bireylere çalışıp çalışmadıkları sorulmuş ve her iki grupta toplam 146 kişiden cevap alınmıştır. Kırsal alandaki engellilerin önemli bir bölümü çalıştırılmamakta veya elverişsiz koşullar nedeniyle çalışamadığ tespit edilmiştir. Engellilerde ilk ve son yaş grupları hariç diğer yaş gruplarında çok düşük bir seviyede çalışma durumu söz konusudur. Engellilerin maruz kaldığı zor durumlar, güç koşullar, çalışma ortamlarının yetersizlik ve elverişsizliği gibi daha birçok neden toplumsal konum ve statülerine de yansımaktadır. Toplumsal hayata tam ve etkin bir şekilde katılım sağlayamadıkları (Hüseyinli, 2017, 139) önyargısı sebebiyle, ayrımlar, uzaklaştırılmalar, uyumsal güçleştirmeler ve daha birçok engelleme ortaya çıkmaktadır. Kentsel toplumsal alanda dahi iyileştirmeler kısmi bir ilerlemeyle yetersiz düzeydeyken, kırsal alanda engelli bireylerin çalışma durumları, düzeyleri ve koşullarının elverişliliğinden bahsedilemez.

Engellilerin çalışma hayatıyla ilgili önemli bir bulgu daha az ücretle çalıştırıldıkları ve belli bir süre sonra işten çıkarıldıklarına yöneliktir. Engelli bireyler istihdam edildikleri yerlerde önyargı ve ayrımcı uygulamaların hedefi olurken (Haq, 1994), 5378 Sayılı Kanunun 14. Maddesi'nde yer aldığı gibi yasal düzenlemelerle ayrımcılıkların önüne geçilmişse (EHK, 1 Temmuz 2005) de söz konusu durum uygulamada gerçekleştirilememektedir. Aynı zamanda sosyal politika ve güvenliğin bir gereği olarak çalışma hayatına katılımlarının önü açılmaya çalışılmaktadır. Uygun iyileştirici eğitim, örgün eğitim ve modern rehabilitasyon hizmetlerinin verildiği engelliler, iyileştirilmiş ekonomik verimlilikle hayata daha özgür bir şekilde katılabilmektedir. 
Tablo 4: Engelli bireylerin iș alanlarına/mesleğine göre dağılımı.

\begin{tabular}{lcc}
\hline İş alanı/Mesleği & $\boldsymbol{f}$ & $\mathbf{\%}$ \\
\hline Evde çalışan & 3 & 18,75 \\
İşveren & 3 & 18,75 \\
Kamuda işçi & 2 & 12,5 \\
Memur/Uzman vd. & 1 & 6,25 \\
Özel sektör işçi & - & - \\
Özel sektör yönetim & - & - \\
Serbest & 7 & 43,75 \\
Toplam & $\mathbf{1 6}$ & $\mathbf{1 0 0}$ \\
\hline
\end{tabular}

Tablo 3'ten de görüleceği üzere toplam 16 kişinin çalıştığ 1 , tablo 4 ise katılımcıların kamuda işçi olarak ya da serbest alanda çalıștıkları görülmektedir. Her birey gibi engellenenlerin de toplumsal ilişkiler alanının önemli bir aşamasını oluşturan çalışma hayatında var olma hakları sözleşmelerle garanti altına alınmış olsa da yukarıdaki veriler bize uygulamada yeterli düzeye ulaşılamadığını göstermektedir. Nitekim ifade gücü yerinde ve güçlü bireylerin meslekleri arasında ayrımcılık öne çıkmış ve bu durum işgücü piyasası içinde yapısal eşitsizliğin temel bir nedeni durumundayken, uygulama denetiminin yetersizliği engelli bireylerin beşeri sermayelerinde ve çalışma hayatında daha derin eşitsizlikler ile ayrımcılıklar yaşamalarına neden olmaktadır (Maroto \& Pettinicchio, 2014). Yukarıdaki tablo 3 ve 4 'te görüleceği üzere, engellilerin çalışma hayatına katılım ve meslek edinmeleri yeterli düzeyde olmadığını gösterirken, aynı zamanda çalıșan her üç kișiden ikisinin çalıșmaya ilişkin haklarını tam olarak bilememesi, toplumsal alandaki yaşamsal zorluklar nedeniyle çalışmak istememeleri yeterli sayıda hizmet ve düzenleme ihtiyacını göstermektedir.

Engelli bireylerin çalışma ve ev arasındaki ilişkileri toplumsal alışkanlık ve sosyal ilişkilerinin düzenlenmesinde de etkilidir. Çalışmada, kırsal alandaki engelli bireylerin \% 90'a yakın bir kesiminde yaşam ve çalışma alanları birbirinden farklılaşmadı̆̆ 1 ortaya çıkmıştır. Bu nedenle sosyal ilişkiler de çoğunlukla ev hayatı çevresinde gelişmiştir. Sosyal ilişkilerde engellerin ve aile çevresinde yaşayan bireylerin olumsuz etkilenme durumları, çoğunlukla bakımlarla ilişkili bir şekilde gelişmektedir. Özellikle evlenme/evlenememe durumlarındaki olumsuzluklar belirgin olduğundan, engelli bireylerin aile durumu aile içinde medeni durumları ve engellilik arasındaki görünür bağlantıların ortaya çıkarılması gerekir.

Tablo 5: Katılımcıların engellilik durumlarının kendi veya aile bireylerinden birinin medeni durumlarına etkileri.

\begin{tabular}{|c|c|c|c|}
\hline Medeni durum ilişkisi & $\begin{array}{c}\text { Birinci } \\
\text { Grup } \\
\quad f\end{array}$ & $\begin{array}{c}\text { İkinci } \\
\text { Grup } \\
\quad f\end{array}$ & $\begin{array}{c}\text { Toplam } \\
\qquad f\end{array}$ \\
\hline Medeni durumum arasında ilişki vardır & 33 & 3 & 36 \\
\hline Medeni durumum arasında ilișki yoktur & 13 & 60 & 73 \\
\hline Herhangi bir aile bireyinin medeni durumu arasında ilişki vardır & 3 & 1 & 4 \\
\hline Herhangi bir aile bireyinin medeni durumu arasında ilişki yoktur & 14 & - & 14 \\
\hline $\begin{array}{l}\text { Hem benim hem de aile bireylerinden en az birinin medeni } \\
\text { durumu arasında ilişki vardır }\end{array}$ & 2 & 1 & 3 \\
\hline $\begin{array}{l}\text { Ne benim ne de aile bireylerinden en az birinin medeni durumu } \\
\text { arasında ilişki yoktur }\end{array}$ & 11 & 1 & 12 \\
\hline Fikrim yok & 5 & 2 & 7 \\
\hline Diğer & 2 & - & 2 \\
\hline
\end{tabular}


"Engelli bireyler evlenme biçimi ve ilişkileri”, "evli veya boşanmış engelli insanların bağımlı çocukları olma olasılığına ilişkin durum" gibi soru ve sorunlar toplumsal hayatta tartışılan önemli konulardandır. Bu tür soru veya sorunların cevabını ortaya çıkarmadıkça, engellilik ve aile formasyonu kalıpları arasındaki bağlantıları tam anlamıyla bilmek mümkün değildir. Engellilerin mevcut evlilik düzeyleri, boşanma ve çocuk sayısı gibi durumlar farklı düzeylerde olduğundan üzerinde daha fazla çalışma yapmaya ihtiyaç vardır. Dolayısıyla, bu sorulara ilişkin kavramsal veya düşünsel neden-sonuç sorununu çözmek tek başına bir çalışmanın konusu olacağından bu çalışmada yalnızca medeni durumla ilişkili analize yer verilmiştir. Hane içinde engelli bireylerin engellilik düzeyi yükseldikçe ailenin herhangi bir üyesinin ya da engelli bireyin kendi medeni durumu da önemli ölçüde değişebilmektedir. Aile faktörü engelli bireyin medeni durumunda etkili olabildiği gibi, engellinin engel durumu da hem karş1 tarafı hem de kişinin kendi durumunu etkileyebilmektedir. Elbette, her iki faktörün de aynı anda hareketi söz konusu olabilir ve hatta aynı anda aile durumu da engelli bireyin medeni durumunun farklılaşmasında hem neden hem de sonuç olabilir. Engellinin medeni durumu; ailenin ekonomisi, çevresel etkisi, ilişkilerinin yanı sıra engellinin yaşı, cinsiyeti ve statüsüsel özelliklerinin oynadığ rolle de ilgilidir. Yaşlanan engelli bireylerin bakım alma ihtiyacı genç olanlara nazaran daha yüksektir. Ancak yaşın medeni durumunu engelleyen geçerli tek neden olmadığı da ortadadır (Clarke \& McKay, 2008, 35). Kısacası, aslında bağlantı yalnızca yaş nedeniyle kurulduğu zaman, genç engellilerin yüksek evlilik oranlarına sahip olduğu sonucuna varma tehlikesi vardır. Gelirler konusunda da benzer bir noktaya ulaşılabilir. Engelliler ortalamadan daha yüksek gelire sahip ise erken evlenebilir düşüncesiyle yanlışa düşülmektedir. Dolayısıyla, anlamak zorunda olduğumuz soru, engelliliğin bu tür farklılıkları dikkate alarak aile kurma durumuna ne kadar bağımsız bir fark yarattığıdır. 18 yaşından büyük 118 katılımcıya; engellilik durumlarıyla kendi medeni durumları ve engellilik durumlarıyla aile bireylerinden en az bir kişinin medeni durumu arasındaki ilişkiye göre değişim durumu sorulmuştur. Birinci grupta yer alan 53 kişiden 33'ü engellilik durumları ile medeni durumları arasında; 3'ü aileden bir bireyin medeni durumuyla ve 2 kişide hem kendi hem de aileden herhangi bir kişinin medeni durumuyla ilişkili olduğunu belirtmiştir. İkinci grupta da 65 katılımcıdan 3'ü engellilik durumları ile medeni durumları arasında, 1 kişi de engellilik durumu ile aileden en az bir kişinin medeni durumu arasında ilişki olduğunu belirtmiştir. Birinci gruptan 5 kadın ve 2 erkek, ikinci gruptan da 1 erkek engellilik durumları nedeniyle boşanmak/ayrılmak zorunda kalmış veya bırakılmıştır. Boşanma/ayrılma durumuna ilişkin katılımlar çoğunlukla olumsuz olarak belirtilmiştir. Birinci gruptan 2 katılımcı herhangi bir şekilde bir ilişki düşünmediğini, hazır olmadığını söylemiştir. Birinci grupta yer alanların, ikinci grupta yer alanlara göre kişisel medeni durumlarının yanı sıra, aileden birinin evliliğini ya da diğer medeni ilişki durumlarını daha fazla olumsuz etkilediği veya geciktirdiği sonucu ortaya çıkmıştır.

Engelli bireylerin engellerinin hane üyelerinden birinin medeni durumunu olumsuz bir şekilde yüksek derecede etki etmemesi, ailenin olağan istikrarının da devam etmesini mümkün hale getirmekte ve tüm aile üyelerinin yaşam memnuniyetini arttırmaktadır (Sobsey, 2004). Engellilerin yaşam memnuniyetinin artmasının bir koşulu da toplumsal alanda engelin gerçekte bilinmesidir. Özellikle kırsal alanda söz konusu engelin bilinip, engele göre hareket edilme durumundaki bilinçsizlik engeli tüm aile üyeleri için korkutucu ve çekilmez bir hale getirebilmektedir. Engellilerin için sosyalleşme ve çalışma alanlarındaki yasal düzenlemelerin yetersizliği memnuniyetsizliğin artmasına ve duygusal karışıklıkllara neden olmaktadır. 
Tablo 6: Yasal düzenlemelere ilişkin duygusal durum ile cinsiyet arasındaki ilişki

\begin{tabular}{lrrrrrrr} 
& \multicolumn{9}{c}{ Cinsiyet } & & & \\
\cline { 5 - 7 } Duygusal Durum & $\boldsymbol{f}$ & $\boldsymbol{\%}$ & $\boldsymbol{f}$ & $\boldsymbol{\%}$ & $\boldsymbol{f}$ & $\boldsymbol{\%}$ \\
\hline Olumlu & 5 & 2,60 & 9 & 4,67 & 14 & 7,27 \\
Olumsuz & 66 & 34,38 & 89 & 51,56 & 155 & 85,94 \\
Cevap yok & 13 & 6,77 & 10 & 5,21 & 23 & 11,98 \\
Toplam & 84 & 43,75 & 108 & 56.24 & 192 & 100 \\
\hline
\end{tabular}

Engellilerin yaşam memnuniyetine ilişkin sorunlarının odak noktası duygusal sağlık yetersizliğiyle ilgilidir. Bu kavramla ne demek istediğimiz konusunda net olmak önemlidir. Burada engellilere yönelik düzenlemelerden tatmin olmanın da ötesinde genel anlamda engellilerin psiko-duygusal dünyalarında pozitif ya da negatif yönlü değişimin ne olduğu öğrenilmeli ve gözlemlenmelidir. Toplumsal yaşamın farklı alanlarında hayatlarını devam ettiren her birey bazen geçici bazen de sürekli duygusal ve psikolojik zorluklarla karşılaşabilmektedir (Watson \& Maitre, 2014). Dolayısıyla benzer durumun engelliler için de ortaya çıkabileceği çoğunlukla unutulmaktadır. Bu nedenle, engelli bireylerin kendilerine yönelik düzenlemelerle ilişkili duygusal yaklaşımlarının ne olabileceği araştırma noktalarından biri olmuştur. Bu bağlamda katılımcıların sosyal politika ve güvenlik konularına duygusal yaklaşımlarının yönü cinsiyet durumları dikkate alınarak sorulmuştur. Erkekler açısından çok az olumlu bir eğilim ötesinde, cinsiyet durumunun duyguların olumlu veya olumsuz olması yönünde çok belirleyici olmadığı, katılımcı dağılımlarının genel eğilimde olduğu görülmüştür. Katılımcıların sosyal güvenlik ve politikayla ilişkili duygusal yaklaşımları çoğunlukla negatif yönlüdür. Çok önemli bir değişim görülmese de erkekler az bir farkla (kadınlar $\% 2,6$ iken, erkekleri \%4,67) yasal düzenlemelere olumlu bir duyguyla bakmaktadırlar. Söz konusu durum genel dağılım içinde \%1,3 düzeylerindedir. Her iki cinsiyet grubunda olumsuz duygular yoğunlaşırken, söz konusu olumsuz yaklaşım toplamda $\% 85$ ' in üzerindedir.

Tablo 7: Engellilerin sosyal politik düzenlemelere ve aile içi ilişkilere yönelik algıları

\begin{tabular}{|c|c|c|c|c|c|c|}
\hline \multirow[b]{3}{*}{ Aileye ilişkin algıları } & & & \multicolumn{4}{|c|}{ Sosyal Düzenlemelere Ulaşım Durumu } \\
\hline & \multicolumn{2}{|c|}{ Yeterli } & \multicolumn{2}{|c|}{ Yetersiz } & \multicolumn{2}{|c|}{ TOPLAM } \\
\hline & $f$ & $\%$ & $f$ & $\%$ & $f$ & $\%$ \\
\hline Ailem hiçbir sorun yaşamıyor & 10 & $\% 5,2$ & 4 & $\% 2,1$ & 14 & $\% 7,3$ \\
\hline Ailem kısmen sorun yaşıyor & 6 & $\% 3,1$ & 38 & $\% 19,8$ & 42 & $\% 22,9$ \\
\hline $\begin{array}{l}\text { Ailem temel bakım ve ihtiyaçlarım } \\
\text { konusunda sorunlar yaşıyor }\end{array}$ & - & - & 9 & $\% 4,65$ & 9 & $\% 4,65$ \\
\hline $\begin{array}{l}\text { Ailem ekstra ihtiyaçlarım konusunda } \\
\text { sorun yaşıyor }\end{array}$ & - & - & 86 & $\% 44,8$ & 86 & $\% 44,8$ \\
\hline $\begin{array}{l}\text { Ailem ekonomik yük olduğumu } \\
\text { düşünüyor }\end{array}$ & 3 & $\% 1,7$ & 22 & $\% 11,45$ & 25 & $\% 13,15$ \\
\hline $\begin{array}{l}\text { Ailem utanç veya suçluluk duygusu } \\
\text { taşıyor }\end{array}$ & 2 & $\% 1,0$ & 12 & $\% 6,2$ & 14 & $\% 7,2$ \\
\hline Toplam & 21 & $\% 11,0$ & 171 & $\% 89,00$ & 192 & $\% 100$ \\
\hline
\end{tabular}

Sosyal düzenlemelerle engelli bireylerin ailelerine ilişkin algıları arasındaki ilişki katılımcılara sorulmuş ve tablo 7'deki durumlardan en çok hangisine yakın bir alg1 taşıdıklarını işaretlemeleri istenmiştir. Katılımcıların önemli bir bölümü bir şekilde sorunlar yaşadığını ve sosyal düzenlemelerin yetersizliğini dile getirmiştir. "Ailem hiçbir sorun yaşamıyor" diyenler hariç geriye kalan ve aile ile durumlarına ilişkin olumsuz algıya sahip katılımcıların az bir bölümü $(\% 5,8)$ sosyal düzenlemeleri yeterli 
görmektedir. Buna karşın, katılımcıların büyük bölümü (\% 89) sosyal düzenlemelerin yeterli olmadığını belirtmiştir. Engelli bireylerin yakın sosyal çevresiyle ilişkileri ve onlarla elverişli sosyal alışverişin hem ruh sağlığ hem de kişisel duygusal refah üzerinde olumlu etkileri bulunmaktadır (Pruchno \& Rosenbaum, 2003, 487-491) Düzenlemelerle birinci gruptaki engellilerin ikinci gruptakilere göre daha az olumlu değişim firsatları olabilir ve bu nedenle ruh sağlığı ve refahı üzerindeki etkileri daha az avantajlı olabilir (Tough vd., 2017). Psikolojik, çevresel ve toplumsal ilişki ile etkilenmelerin düzeyini öğrenmek için her iki gruptaki kişilere yönelik ruh sağlığı ve refahı ile sosyal ilişkilerini araştıran nicel çalışmaların sistematik olarak gözden geçirilmesi ihtiyacı ortaya çıkmaktadır.

Tablo 8: Engelli bireylerin katılamadığg topluluk aktiviteleri (Birden fazla seçenekli).

\begin{tabular}{lccccc}
\hline \multirow{2}{*}{ Yapılan etkinlik türü } & \multicolumn{2}{c}{ Birinci Grup } & \multicolumn{2}{c}{ İkinci Grup } & Toplam \\
\cline { 2 - 6 } & $\boldsymbol{f}$ & $\boldsymbol{\%}$ & $\boldsymbol{f}$ & $\boldsymbol{\%}$ & $\boldsymbol{f}$ \\
\hline Spor & 17 & $\% 16,66$ & 13 & $\% 14,44$ & 30 \\
\hline Gezi & 23 & $\% 22,54$ & 82 & $\% 91,11$ & 105 \\
\hline Kişisel alışveriş̧ & 11 & $\% 10,78$ & 65 & $\% 72,22$ & 76 \\
\hline Aile ve diğer alışveriş vb. & - & - & 36 & $\% 40,00$ & 36 \\
\hline $\begin{array}{l}\text { Konser, sinema, tiyatro, } \\
\text { etkinlik }\end{array}$ & 2 & $\% 1,96$ & 3 & $\% 3,33$ & 5 \\
\hline Dini sohbet, ibadet vb. & 3 & $\% 2,94$ & 71 & $\% 78,88$ & 74 \\
\hline Hiçbir şey yapmiyorum & 74 & $\% 72,54$ & 5 & $\% 5,55$ & 79 \\
\hline Diğer & - & - & 2 & $\% 2,22$ & 2 \\
\hline
\end{tabular}

Birinci grup (102 kişi) ile ikinci gruptaki (90 kişi) katılımcıların tamamına ne tür etkinlikler yaptıkları sorulmuştur. 192 katılımcıdan 405 farklı cevap alınmıştır. Her grup hem kendi grup evreni hem de genel grupla karşılaştırılmıştır. Her iki gruptaki katılımcılar çoğunlukla gezdiklerini söylemişlerdir. İkinci gruptaki bireyler spor etkinliği hariç diğer tüm etkinliklere daha fazla katılabilirken, aynı şekilde kişisel ve ailevi alışverişlere de daha çok katılabilmektedirler. Birinci grupta hiçbir şey yapamadığını belirtenlerin sayısı oldukça fazla olup, bu grupta gezi ve spor yapma oranı diğer aktivitelere göre biraz daha yüksek çıkmıştır. Dini etkinliklere katılım durumu yine ikinci grupta daha yoğun görülmektedir. Toplumsal alandaki her birey kendine has bir sosyalleşme alanı oluşturmakta ve bazen bu sosyalleşme alanları ya da süreçlerine farklı aktiviteler dahil edebilmektedir. Sosyalleşmenin önemli bir faktörü de dindir (Bucuka, 2019). İçinde yaşanılan toplumun dinsel etkinlik ve yerlerine katılım sosyalleşmeyi de artırabilmektedir. Aynı zamanda halkla başarılı iletişim kurmak, sağlıklı ilişkilerde bulunmak müzik, gezi, spor gibi aktivitelere katılımlar da söz konusudur. Sosyalleşmenin bir yönü de çalışma hayatına katılımla ilişkilidir. Ancak tablo 3 ve tablo 4 'te de görüleceği üzere çalışma hayatına katılım durumu ile meslek edinme süreçleri oldukça kısıtlıdır.

Engellilere ilişkin duygusal ve medeni durum onların sosyal hayata katılımının önündeki başka engellerdendir. Engellilik durumu kimi zaman eş veya partner olmada reddedilmeye neden oluşturmaktadır. $\mathrm{Bu}$ durum engelli bireylerde engellilikten kaynaklanan keder, depresyon, ekonomik bağımlılık gibi duygusal sorun (IAPSRS, 1985) ve rahatsızlıkları ortaya çıkarmaktadır. Bunun temel sebebi engelli olmayan bireylerin "ötekiler" olarak gördüğü engellilerin engellerine ilişkin olumsuz tepkileridir. Oluşturulan olumsuz tepkiler engellerin de artmasına neden olmaktadır. Gelişmekte olan ülkelerde yapılan çalışmaların önemli bir bölümünde de görüleceği üzere 
engellilerin bir bölümünün aileleri onları yük olarak görmekte ve olumsuz tutumlar geliştirmektedir (Altman, 1981).

İnsanlar bir araya gelerek toplumsallaşmayı sağlamaya ve yaşamsal varlığını sürdürmeya çalışır. Ancak, handikap ${ }^{1}$ içindeki bireylerin sosyal ayrımı son derece yaygın iken, gelişmiş ülkelere benzer şekilde gelişmekte olanların da sosyal düzenlemeler gerçekleştirmeleri gerekmektedir. Gelişmiş ülkeler için de sosyal düzenlemelerin yeterli olduğu iddia edilemez, engelli bireylerin eğitilmelerinin, rehabilite edilmelerinin ve hatta bir nebze de olsa istihdam edilmelerinin önündeki engeller kaldırılmış olsa da özellikle kırsal alanlarında yaşayan engellilerin sosyal ayrımı son derece yaygındır (Brown, 1988). Kırsal alanda sosyal düzenleme ve hizmetler halen engelliler için özel ayrıcalıklar sunmamaktadır. Engelli dostu ortamın yokluğundan engelli insanların çok daha büyük sorunlarla karşılaşmaları daha olasıdır. Engelliler için büyük sorunların alanı durumunda görünen kırsal alanlara yönelik düzenlemelere katkı olması açısından yapılan bu çalışmada elde edilen veriler analiz edildiğinde engellilerin sorunlarının devam ettiği ve çoğunlukla birinci gruptakilerin bu sorunları yaşadığı, bir kısmının duyarsızlık, zulüm ve acıma ile karşı karşıya olduğu görülmektedir.

\section{SONUÇ}

Engelli dostu ortam ve sosyal çevre oluşturmanın yolu, sosyalleşme sürecine bağlı olduğu kadar yasaların çerçevelenmesi ile uygulanmasına, engellilere yönelik acil ihtiyaçlar için gerekli kaynakların önceliklendirilmesine ve politika yapıcıların, kamu idaresinin güvenlikle ilgili hizmet sunumlarına da bağlıdır. Dolayısıyla diğer benzer uygulamalı çalışmalarda olduğu gibi, bu çalışma da sosyal düzenlemelerin gerçekleştirilmesi için politika yapıcılara rehberlik edebilir.

Çalışmanın sonuçları her ne kadar örneklem bakımından Batman, Mardin, Şırnak ve çevresindeki kırsal alanda yaşayan engellilerle ilgili olsa da genel itibariyle Türkiye kırsalında yaşayan engellilerin yaşam kalitesini de gözler önüne sermektedir. Kırsalda yaşayan engellilerin yaşam durumları, sıkıntıları, sorunları ve etkilendikleri diğer olumsuz durumlar, ailede, sosyal yaşantıda, çalışma alanında nihayetinde birincil veya ikincil ilişkilerinde engellerle karşılaştıklarını göstermektedir.

Engellilere yönelik düzenlemeler ve yaklaşımlarda bazı değişiklikler olmasına rağmen, engelli insanların ana akım topluma rahatça entegre olabilmeleri için halen düzenlemelere ihtiyaç vardır. Ekonomik, teknolojik, ulaşım, iletişim, mekânsal gelişim gibi dinamikleri diğer alanlarla karşılaştırıldığında sürekli nostaljinin, geleneğin ve temelde geriliğin temsilcisi olarak görülen kırsal alanda engellilere yönelik düzenleme ve çalışmaların uygulama şekilleri azdır. Düzenleme eksiklerinin temel sebebinin, toplumsal alanda engellilere yönelik hasta oldukları, iyileşemeyeceklerine ilişkin egemen yanlış düşüncenin yaygınlığıdır. Engelliliğin kırsal alandaki etkisi bu çalışmayla raporlaştırılırken, bu egemen düşüncenin kırılabilmesi için özellikle sosyal ve diğer bilim alanlarında kırsal engellilikle ilgili çalışmaların arttırılması gerekliliği öne çıkmaktadır.

\footnotetext{
${ }^{1}$ Dünya Sağlık Örgütü tanımlamasına göre İngilizce'de handicap kelimesinden türetilen engellilik küçük düşürücü bir anlamı çağrıştırdığından onun yerine yetiyitimi kavramının kullanımı önerilmektedir.
} 
Engelli bireylerin yaşamı kendisi için sınırlı bir sosyalizasyon süreciyle çevrilidir. Dışardakilerin, diğerlerinin farklı yaşamları, düzenleme ve uygulama yetersizlikleri de engelli bireylerin yaşamını sınırlandırmaktadır. Engelli olmayanların yaklaşımları genellikle cehalet, önyarg1 ve duyarsızlık gibi olumsuz güçlerle komplike hale gelmiştir. $\mathrm{Bu}$ komplike durumun kırılması, engellilere sosyal alanda ayrılan yerle ilişkilidir. $\mathrm{Bu}$ yer aynı zamanda engellilere eğitim verilmesi, rehabilite edilmeleri ve istihdamlarının sağlanmasıyla mümkündür. Çalışmada değinildiği üzere Türkiye'de yasal düzlemde bu haklar verilmiş görünmektedir. Ancak uygulamadaki kısıtlar ve yer yer ekonomik yetersizlikler kırsal alanda engellilere yönelik yaşamsal aktivitelerin yapılmasına olanak vermemektedir. Engelliliğe yönelik düzenlemeler her ne kadar devlet eliyle yasalaştırılmışsa da engellilerin yaşam şartlarını sosyal ve ekonomik olarak üretken hale getirmek, aynı zamanda STK'ların da temel görevleri arasındadır. STK'lar çalışmalarında kırsal alanda yaşayan engelli haklarına, ayrıcalıklarına ve mevcut yasalar ile düzenlemeler hakkında da yer vermelidir. Kitle iletişim araçlarının katılımı, tüm ulus için genel bir engellilik farkındalık programı için çok önemlidir. Engellilere ve ailelerine devlet tarafından mali teşvik şeklinde bir ödenek sunumu olsa da bakım hizmetleri ve diğer yaşamsal hizmet ile aktivitelerin geliştirilebilmesi için farkındalık tüm alanlarla gerçekleştirilmelidir. Genel olarak, sağlik, eğitim, sosyal refah ve ülke içindeki kurumlar da dahil olmak üzere çoğu hizmet, engellilerin ihtiyaçlarına göre uyarlanmalıdır ve yasalar buna göre çerçevelenmelidir. Toplum temelli rehabilitasyon programı modeli için restoratif geleneklerden tutumsal bir değişim için itici güç sağlayıp, rehabilitasyon çalışmalarıyla uyumlu bir çerçeveyle birleştirebilir.

Araştırmada elde edilen bulgular genel popülasyondan daha az tutarlı olup, sosyal ilişsilerin özellikle ikinci grupta sağlık ve refahta önemli bir rol oynadığ sonucuna varılmıştır. Engellilerin ilişki kalitesi, gücü ve yalnızlığı yapılar ve bireyler arasında karşılıklılığın kararsızlığı arasında değişmektedir. Onun için, engelli bireyleri sosyal ağlara entegre etmek önemli bir çaba olmakla birlikte, ilişkilerinin kalitesini güçlendirmek ve destek düzeyini ve türünü ihtiyaçlarına göre uyarlamak önemlidir. Sağlık durumuyla birlikte, duygusal durum ve refahını teşvik etmek için, rehabilitasyon uzmanları engelli bireyleri desteklemelidir. Engellilerin sosyal hayatta diğer kişilerle yüksek kaliteli ilişkiler kurabilmesi ve sürdürebilmesi için yeterli desteğin sağlanması gerekir. Bu toplum temelli rehabilitasyon programı ile aile bireyleri başta olmak üzere diğer kesimlere de özel bir davranış danışmanlığ programı ile sunulabilir. Şu gerçek bilinmelidir ki, engelli bireylerin yaşam kalitesini artırmanın yolu toplumsal tutumu değiştirmekten geçmektedir. Engellilerle temasa ilişkin olumsuz yaklaşımları kırmak için engelli ve engelli olmayanların temasını artırmak gerekir. Sosyal politikanın gereği olarak, bu da öncelikle idare ve temsil makamını en üst mercide elinde bulunduran politika yapıcılarının görevidir.

\section{KAYNAKÇA}

Abu-Habib, Lina. Gender and disability: Women's experiences in the Middle East, Oxford: Oxfam, 1997.

Altman, Barbara M. "Studies Of Attitudes Toward The Handicapped: The Need For A New Direction". Social Problems, 28/3 (1981), 321-337, https://doi.org/10.2307 /800306

Barbotte, Eric vd.. "Prevalence Ofimpairments, Disabilities, Handicaps And Quality Oflife In The General Population: A Review Of Recent Literatüre". Bulletin of the World Health Organization, 79/11 (2001), 1047-1055. 
Barnartt, Sharon. "Report of the ASA Committee on the Status of Persons with Disabilities (PWD)". American Sociology Association. 2011. http://www.asanet.org/ images/asa/docs/pdf/Disabilities\%20Status\%20Committee\%20Report\%202005.pdf.

Brown, Roy I. "Quality Of Life And Rehabilitation: An Introduction”. Quality Of Life For People Handicapped People. ed. Brown, Roy I. p.2-5, New York: Croom Helm, 1988.

Bucuka, Yunus. "Engelliler, Din ve Sosyal Dışlanma". Bingöl Üniversitesi Sosyal Bilimler Enstitüsü Dergisi, 9/18 (2019), 899-929, https://doi.org/10.29029/ busbed.581022.

Clarke, Harriet \& McKay, Stephen. "Exploring disability, family formation and breakup: Reviewing the evidence". Department for Work and Pensions Research Report (2008), https://lx.iriss.org.uk/sites/default/files/resources/rrep514.pdf

Corbin, Juliet \& Strauss, Anselm L. "Managing chronic illness at home". Qualitative Sociology, 8 (1985), 224-247.

Denzin, Norman K. \& Lincoln, Yvonna S. "Introduction: The Discipline and Practice of Qualitative Research". The Sage handbook of qualitative research. Eds. Denzin, Norman K. - Lincoln, Yvonna S., p. 1-32. Sage Publications Ltd, 2005.

Doğanay, Gülmelek \& Henden, Şölen K. "Kır ve Kentin "Öteki" Kadınları: Trabzon'da Engelli Kadınlar". 4. Uluslararası Kentsel ve Çevresel Sorunlar ve Politikalar Kongresi, (20-21 Ekim 2016), İstanbul, 2016.

Duman, Nezahat A. \& Doğanay, Gülmelek. “Toplumsal Dişlanma Pratikleri Üzerinden Trabzon'da Engelli Kadınlar”, Sosyoloji Araştırmaları Dergisi, 20/2 (2017), 1-48, https://doi.org/10.18490/sosars.345505

EHK, Engelliler Hakkında Kanun. Resmi Gazete 5378 (1 Temmuz 2005) 12 Ocak 2020 https://www.mevzuat.gov.tr/Mevzuat Metin/1.5.5378.pdf

Haq, Sirinivas. (1994). "Policies and Programs Concerning Disabilities and People With Disabilities In Bangladesh". Proceedings of the Regional Seminar on Childhood Disability, Public Health Association (2-4 December 1994), Bangladesh: Dhaka, 1994.

Hosain, Gm Monawar. vd.. "Impact of disability of life of rural disabled people in Bangladesh". Centre for Health and Population Research Bulletin, 20/4 (2002), 297305.

Hüseyinli, Namık. vd.. "Çalışma Hayatında Engelli Haklarına İlişkin Yasal Düzenlemeler ve Engellilerin Haklara İlişkin Farkındalıkları”. İnsan ve Toplum Bilimleri Araştırmaları Dergisi, 6/6), 138-152 (2017), İstanbul.

ILO. “Disability and Work”. 23 Ocak 2020. http://www.ilo.org/global/topics /disabilityand-work/WCMS_475650/lang--en/index.htm

Karataş, Kasım \& Çifci, Elif G. "Türkiye'de Engelli Kadın Olmak: Deneyimler ve Çözüm Önerileri”. Uluslararası Sosyal Araştırmalar Dergisi, 3/13, (2010), 147-153.

Kurawa, Sabo Suleiman. "The impact of disability on self and society: an agenda for research on rehabilitation of disabled in Nigeria". Procedia Social and Behavioral Sciences, 5 (2010), 1804-1810, Netherlands: Elsevier, https://doi.org/10.1016/j.sbspro. 2010.07.368

Mahapatra, Sukanta Kumar. "Accessibility And Quality Education Of Persons With Disabilities In India: An Open Schooling Perspective", Pan-Commonwealth Forum 8 
(PCF8) (27-30 November 2016), Open University Malaysia (OUM) Malaysia: Kuala Lumpur, 2016

Maroto, Michelle \& Pettinicchio, David. "Disability, Structural Inequality, and Work: The Influence of Occupational Segregation on Earnings for People with Different Disabilities". Research in Social Stratification and Mobility, 38 (August 2014), 72-92, Elsevier, https://doi.org/10.1016/j.rssm.2014.08.002

Millî Eğitim Bakanlığı. "Özel Eğitim Kurumları Yönetmeliği” Resmi Gazete: 28296 (19 Şubat 2020) 21 Mart 2020 https://www.resmigazete.gov.tr/eskiler/2020/02/202002193.htm

Oliver, Michael. The Politics Of Disablement, USA:Palgrave Macmillian, 1990.

Orhan, Serdar \& Genç, Kemal Gökmen. "Engellilere Yönelik Ülkemizde Özel Eğitim Hizmet Uygulamaları ve Örnek Ülke Karşılaştırması". Sosyal Politika Çalışmaları Dergisi, 35/2, 115-146 (2015), DOI: 10.21560/spcd.35323

Orthotoolkit. "SF-36 OrthoToolKit". 30 Ekim 2019. https://www.orthotoolkit. com/sf$36 /$

Pruchno, Rachel \& Rosenbaum, Jennifer. "Social Relationship in Adulthood and Old Age". Handbook of Psychology. ed. Richard M Lerner vd. Vol:6. 487-496. John Wiley \& Sons Pub. 2003.

Resmi Gazete, "Milletlerarası Sözleşme" 05.01.2020. https://www.resmigazete.gov.tr/ eskiler/2009/07/20090714-1.htm

Schneider, Jospeh W. \& Conrad, Peter. Having Epilepsy: The Experience And Control Of Illness. Philadelphia, PA: Temple University Press, 1983.

Scotch, Richard K. "Politics and Policy in the History of the Disability Rights Movement". The Milbank Quarterly, 67/2, 380-400 (1989), DOI: 10.2307/3350150

Sobsey, Dick. "Marital Stability and Marital Satisfaction in Families of Children with Disabilities: Chicken or Egg?", Developmental Disabilities Bulletin, 32/1 (2004), 62-83.

Thompson, Denise. vd.. Community Attitudes To People With Disability: Scoping Project. University of New South Wales: Research Publications Unit, 2012.

Tough, Hannah. vd.. "Social relationships, mental healthand wellbeing in physical disability:a systematic review", BMC Public Health, 17/414 (2017), 1-18.

Vernon, Ayeshea. \& Swain, John. "Theorizing divisions and hierarchies: Towards a commonality or diversity?”. Disability Studies Today, eds. Barnes, Colin. vd. pp.77-97, USA: Blacwell Publishers, 2002.

Watson, Dorothy \& Maitre, Bertrand. Emotional, psychological and mental health $(E P M H)$ diability, National Disability Authority (NDA), Ireland: ESRI, 2014.

WHO. "İşlevsellik Yetiyitimi ve Sağlığın Uluslararası Sınıflandırılması". Çev. Kabakçı, Elif \& Göğüş, Ahmet. 29 Şubat 2020. https://apps.who.int/iris/bitstream/handle/10665/ 42407/9241545429_tur.pdf?sequence8\&isAllowed=y

Yakkaldevi, Ashok Shivaji. "The Sociology of Disability". Reviews of Literature. 2/3 (2014), 1-10. 